\title{
Lactobacillus sobrius Konstantinov et al. 2006 is a later synonym of Lactobacillus amylovorus Nakamura 1981
}

\author{
Correspondence \\ Miia Jakava-Viljanen \\ miia.jakava-viljanen@evira.fi
}

\author{
Miia Jakava-Viljanen, ${ }^{1,2}$ Anna Murros, ${ }^{3}$ Airi Palva ${ }^{2}$ \\ and Katri Johanna Björkroth ${ }^{3}$
${ }^{1}$ Finnish Food Safety Authority (Evira), Virology, Mustialankatu 3, FIN-00790 Helsinki, Finland
${ }^{2}$ Department of Basic Veterinary Sciences, Microbiology and Epidemiology, PO Box 66, Agnes Sjöbergin katu 2, FIN-00014 University of Helsinki, Finland
${ }^{3}$ Department of Food and Environmental Hygiene, PO Box 66, Agnes Sjöbergin katu 2, FIN-00014 University of Helsinki, Finland

Twelve starch-hydrolysing strains isolated from cattle waste-corn fermentations in the USA were included in a study by Nakamura (1981), resulting in the description of Lactobacillus amylovorus. These strains were Gram-positive, non-spore-forming, facultatively anaerobic, catalase-negative and produced D- and L-lactic acid homofermentatively. There was no growth at $15{ }^{\circ} \mathrm{C}$, but the bacterium grew at $45^{\circ} \mathrm{C}$. The DNA G $+\mathrm{C}$ content was reported as $40.4 \mathrm{~mol} \%$ in the original description (Nakamura, 1981). Based on

Abbreviations: FOS, fructo-oligosaccharides; MLSA, multilocus sequence analysis.

The GenBank/EMBL/DDBJ accession numbers for the pheS and rpoA gene sequences of strains DSM 20531 ${ }^{\top}$, DSM 20532, DSM 16698', AD5, LAB7, LAB8, LAB13 and LAB52 are EU000474-EU000489, respectively.

Supplementary phylogenetic trees and a table showing DNA-DNA relatedness among Lactobacillus strains are available with the online version of this paper.
DNA-DNA hybridization studies, the large Lactobacillus acidophilus group is divided into six groups, A1-A4 and $\mathrm{B} 1-\mathrm{B} 2$, that correspond to the previously assigned species L. acidophilus (A1), Lactobacillus crispatus (A2), L. amylovorus (A3), Lactobacillus gallinarum (A4), Lactobacillus gasseri (B1) and Lactobacillus johnsonii (B2) (Johnson et al., 1980; Lauer et al., 1980; Fujisawa et al., 1992). Although these genome clusters have been designated separate species, they are difficult to distinguish solely on the basis of phenotypic characteristics. Recent EcoRI ribotyping data further suggest that the group should be divided into 14 genotypes, A1-A11 and B1-B3, and gives evidence that some of the Lactobacillus strains identified previously would require reclassification in different species (Ryu et al., 2001). In 2006, Lactobacillus sobrius was described by Konstantinov et al. (2006) in a study dealing with six strains isolated from piglet intestine and faeces. The classification of $L$. sobrius DSM $16698^{\mathrm{T}}$ (Konstantinov et al., 2006) was based on DNA-DNA 
hybridization values, the ability to ferment raffinose and fructo-oligosaccharides (FOS) and the ability to grow at $45{ }^{\circ} \mathrm{C}$. Cell morphology, growth temperature and fermentation abilities seem to be very similar to those of the species L. amylovorus. Based on 16S rRNA gene sequence similarity, Lactobacillus kitasatonis (99\%), L. crispatus (98\%) and L. amylovorus (97\%) were the nearest relatives of the novel species, but their DNA-DNA relatedness was found to be lower than $49 \%$. However, the $16 \mathrm{~S}$ rRNA gene sequence published in the study distinguishing the two species $L$. sobrius and $L$. amylovorus was later revised. On 25 September 2006, the $16 S$ rRNA sequence of $L$. sobrius was updated by the submitter. This revised sequence possesses much higher similarity (99.9\%) to the corresponding sequence of the L. amylovorus type strain.

The high degree of similarity based on our preliminary results between $L$. sobrius, L. amylovorus and L. sobrius/ amylovorus-like strains (Jakava-Viljanen \& Palva, 2007) prompted the present study. Our work was designed to resolve the controversy associated with $L$. sobrius by means of a polyphasic approach including phylogenetic analyses of 16S rRNA and two other housekeeping genes (pheS and $r p o A$ ), numerical analysis of ribotypes and DNA-DNA reassociation experiments.

Three strains of L. amylovorus, DSM 20531 ${ }^{\mathrm{T}}$, DSM 20532 and DSM 20552, two strains of L. sobrius, DSM $16698^{\mathrm{T}}$ and AD5 (supplied by S. Konstantinov, Wageningen University, The Netherlands), and six L. amylovorus/ sobrius-like strains, LAB2, LAB7, LAB8, LAB13, LAB16 and LAB52 (Jakava-Viljanen \& Palva, 2007), were selected for the present study. All strains were cultivated and maintained on MRS medium (Oxoid) and incubated anaerobically at $37^{\circ} \mathrm{C}$, unless otherwise indicated. DNA from Lactobacillus strains was extracted for all analyses by the guanidine thiocyanate method of Pitcher et al. (1989) with the modifications described by Björkroth \& Korkeala (1996).

The similarity between the six Finnish LAB isolates, $L$. amylovorus DSM $20531^{\mathrm{T}}$ and L. sobrius DSM $16698^{\mathrm{T}}$ was investigated by comparing the available $16 \mathrm{~S}$ rRNA gene sequences. The latter sequences and sequences from $L$. sobrius/amylovorus-like strains (GenBank accession nos EF120368-EF120371; Jakava-Viljanen \& Palva, 2007) and those of related species were retrieved and aligned. A tree was constructed from the global alignment by the neighbour-joining algorithm using the BioNumerics 4.6 software package (Applied Maths). Comparison of the sequences of the type strains of L. amylovorus and L. sobrius and L. sobrius/amylovorus-like strains revealed 99.6-99.9\% $16 \mathrm{~S}$ rRNA gene sequence similarity. Supplementary Fig. S1, available in IJSEM Online, presents a neighbour-joining tree deduced using the latest sequences available.

Recently, the application of multilocus sequence analysis (MLSA) using the housekeeping genes that code for the phenylalanyl-tRNA synthase alpha subunit (pheS) and RNA polymerase alpha subunit $(r p o A)$ has been developed for the identification of Lactobacillus species (Naser et al., 2006). The combined use of pheS and $r p o A$ gene sequences offered a reliable identification system for nearly all Lactobacillus species (Naser, 2006). These housekeeping gene sequences were determined for LAB7, LAB8, LAB13, LAB52, DSM 20531 ${ }^{\mathrm{T}}$, DSM 20532, DSM $16698^{\mathrm{T}}$ and AD5. Amplification and sequencing reactions were performed as described by Naser et al. (2005). Fragments of 390 and $513 \mathrm{bp}$ were used for aligning the pheS and rpoA genes sequences, respectively. Neighbour-joining and maximumparsimony trees were constructed using the BioNumerics 4.6 software package (Applied Maths) (Fig. 1 and Supplementary Figs S2-S4). To create the maximumparsimony tree, positions with gaps were ignored and cost settings of $100 \%$ for each possible conversion were applied. The number of bootstrap simulations for both tree types was 500. Regardless of the tree type and the gene studied, all the strains were located in the same branch, but distinct from the other related lactobacillus sequences retrieved from GenBank.

Ribotyping was determined for LAB2, LAB7, LAB8, LAB13, LAB16, LAB52, DSM 20531 ${ }^{\mathrm{T}}$, DSM 20552, DSM $16698^{\mathrm{T}}$ and AD5. HindIII and EcoRI ribotyping procedures were performed as described previously (Björkroth \& Korkeala, 1996). Numerical analysis of the scanned (Hewlett Packard ScanJet $4 \mathrm{c} / \mathrm{T}$ ) ribopatterns was performed using the BioNumerics 4.6 software package (Applied Maths). The similarity between all pairs was expressed by Dice coefficient correlation, and the unweighted pair-group method with arithmetic averages (UPGMA) was used for the construction of the dendrogram. Based on internal controls, $1.6 \%$ position tolerance and $0.6 \%$ optimization were allowed for the bands/patterns. The ribopatterns were compared with the corresponding patterns in the LAB database and identification of the isolates was made on the basis of the locations of the type strains in the clusters, taking into account pattern similarity levels detected in the previous studies utilizing this database. The L. sobrius type strain DSM $16698^{\mathrm{T}}$ and strain AD5 and L. sobrius/ amylovorus-like strains clustered clearly together with the L. amylovorus type and reference strains (Supplementary Fig. S5). Moreover, they shared identical ribotypes. The similarity levels between $L$. sobrius DSM $16698^{\mathrm{T}}, L$. amylovorus DSM $20531^{\mathrm{T}}$ and other strains varied from 60.0 to $100.0 \%$ and $68.7 \%$ to $100 \%$ in EcoRI and HindIII ribopattern analyses, respectively.

DNA-DNA reassociation was determined for LAB7, LAB8, LAB13, DSM 20531 ${ }^{\mathrm{T}}$, DSM 20552, DSM $16698^{\mathrm{T}}$ and AD5. For the DNA-DNA reassociation experiments, the DNA was purified and fragmented according to $\mathrm{Huß}$ et al. (1983). In this procedure, DNA was dialysed using Cellu•Sep cellular tubular membranes with a $12000-$ $14000 \mathrm{Da}$ pore size (Orange Scientific). The first dialysis was against $1 \times \operatorname{SSC}(0.15 \mathrm{M}$ sodium chloride and $0.015 \mathrm{M}$ sodium citrate; Amresco) containing $10 \mathrm{mM}$ EDTA and the second against $1 \times$ SSC. The DNA was fragmented three times in a mini French pressure cell (Spectronic 


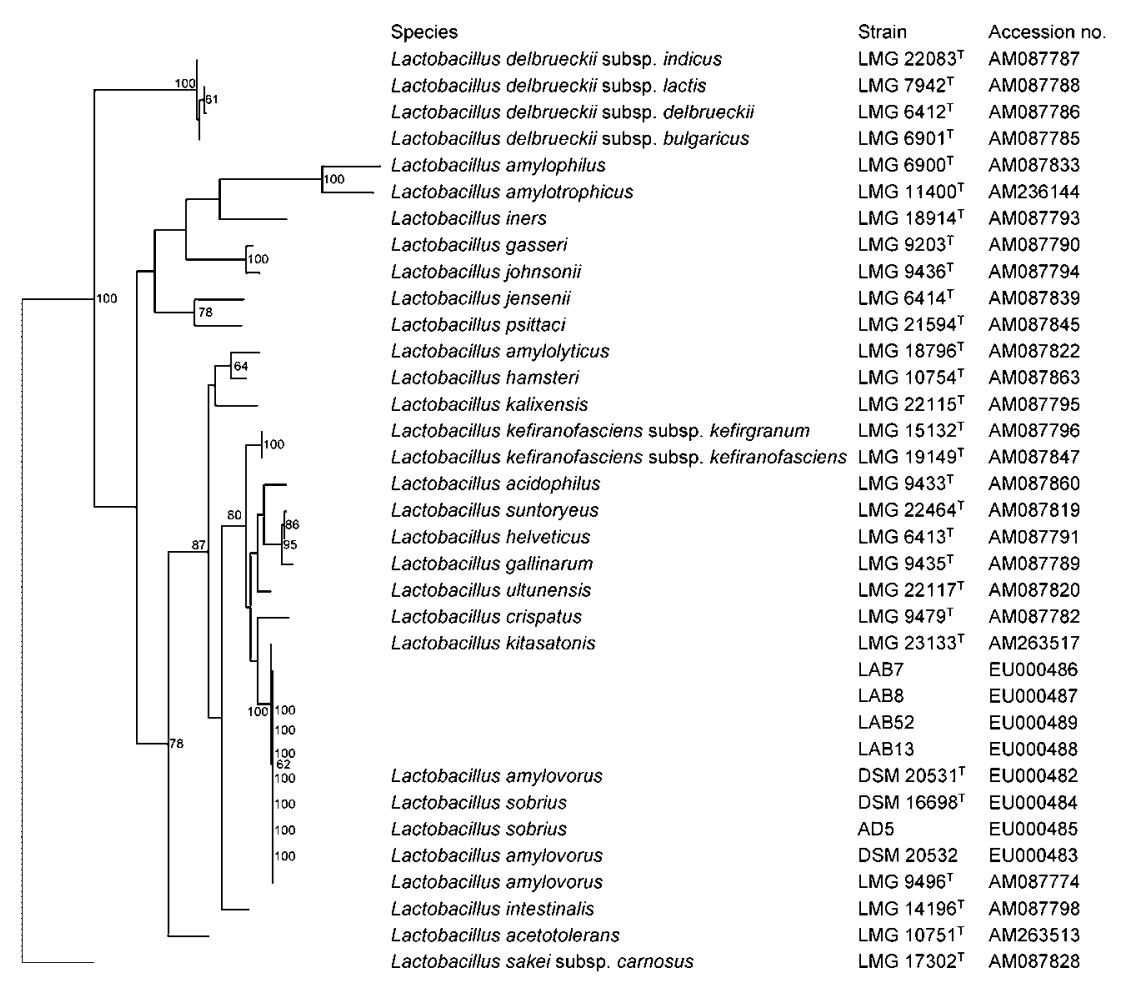

Fig. 1. Maximum-parsimony tree based on the $r p o A$ gene sequences of strains of the Lactobacillus acidophilus group. Bootstrap percentages after 500 simulations are shown. Lactobacillus sakei subsp. carnosus LMG $17302^{\top}$ was included as an outgroup.
Unicam) at 900 p.s.i. (approx. $6210 \mathrm{kPa}$ ) with a French pressure cell press (SLM-Aminco Spectronic). The fragmented DNA solution was dialysed again against $2 \times$ SSC. Each dialysis was done overnight at $5{ }^{\circ} \mathrm{C}$. The quantity and purity of DNA solutions were determined with an Eppendorf BioPhotometer spectrophotometer from absorbance at 230, 260 and $280 \mathrm{~nm}$. Finally, reassociation measurements were done in $20 \mu \mathrm{l} 2 \times$ SSC containing $30 \%$ formamide. The sample solutions contained DNA of strain $A$, the same amount of DNA of strain $B$ or a mixture of equal amounts of DNA of $A$ and $B(A / 2+B / 2)$. The concentration of DNA in the solutions was $60 \mathrm{ng}^{-1} \mathrm{l}^{-1}$. A fluorescent dye, SYBR green I (Roche Diagnostics), was used to stain doublestranded DNA. A $10^{4}$ final dilution was used for the dye. Three replicates of each sample were made. Fluorescence levels were measured with the LightCycler instrument (Roche Diagnostics) and the LightCycler software was used to visualize the renaturation curves. In the LightCycler protocol, DNA was first denatured at $95{ }^{\circ} \mathrm{C}$ for $10 \mathrm{~min}$. The solution was then cooled to the renaturation temperature of $47{ }^{\circ} \mathrm{C}$ in a few seconds. The fluorescence intensity was measured continuously over $30 \mathrm{~min}$ and the fluorescence data were plotted against time. The renaturation temperature was calculated using the following formulae by Gillis $e t$ al. (1970) and Hutton (1977). Formamide has been shown to decrease the melting temperature and thus the renaturation temperature by $0.60{ }^{\circ} \mathrm{C}$ per \% formamide (Hutton, 1977). To calculate the renaturation temperature the formula $T=(0.51 \times \mathrm{GC} \%+47)-0.60 \times \%$ formamide was used. Renaturation rates were calculated from the renaturation curves as increase in fluorescence/time $(\Delta F / \Delta t)$.
Reassociation values were calculated according to the formula of De Ley et al. (1970) as $100 \times\left(4 V^{\prime}{ }_{\mathrm{M}}-V_{\mathrm{A}}^{\prime}-V_{\mathrm{B}}^{\prime}\right) /$ $\left(2 \sqrt{ }\left(V_{\mathrm{A}}^{\prime} \times V_{\mathrm{B}}^{\prime}\right)\right)$, were $V^{\prime}{ }_{\mathrm{M}}$ is the renaturation rate of the DNA mixture of two strains and $V_{\mathrm{A}}^{\prime}$ and $V_{\mathrm{B}}^{\prime}$ the renaturation rates of DNA from individual strains. Hybridizations were performed between $L$. sobrius, $L$. amylovorus and L. amylovorus/sobrius-like strains. All strains studied showed high DNA-DNA relatedness values, in the range of 79 to $121 \%$, indicating clearly that the two taxa represent the same species. A DNA-DNA hybridization value of $85 \%$ was found between the type strains of the two species (Supplementary Table S1). Previous data by Konstantinov et al. (2006) reported a DNA-DNA relatedness value for L. sobrius DSM $16698^{\mathrm{T}}$ and $L$. amylovorus DSM $20531^{\mathrm{T}}$ of $49 \%$, which is much lower than the value determined in our study. The DNA-DNA hybridization experiments confirmed the results of our other investigation methods (16S rRNA and housekeeping gene sequencing and ribotyping).

In the present report, DNA-DNA hybridization values indicate unambiguously that strain DSM $16698^{\mathrm{T}}$ and related $L$. sobrius/amylovorus-like strains belong to $L$. amylovorus. This species-level conclusion was supported by numerical analysis of ribotypes, sequence comparison of two housekeeping genes ( $p h e S$ and $r p o A$ ) and also by $16 \mathrm{~S}$ rRNA gene sequence analysis. On the basis of these results, it is proposed that the two species, Lactobacillus sobrius and Lactobacillus amylovorus, be united under the same name; according to the rules of priority (Rules 38 and 42 of the Bacteriological Code; Lapage et al., 1992), the name Lactobacillus amylovorus should be retained, strains of 
Lactobacillus sobrius should be reclassified as such and the name Lactobacillus sobrius should be considered a later heterotypic synonym.

\section{Acknowledgements}

We would like to thank Ms H. Niinivirta for her excellent technical assistance. Financial support from the Academy of Finland (project decision no. 110310 and a grant Doctoral studies of employed persons for M. J.-V.) is gratefully acknowledged. Special thanks are also due to Sergey Konstantinov and Willem de Vos (Wageningen University, The Netherlands, and University of Helsinki, Finland) for supplying strain AD5.

\section{References}

Björkroth, K. J. \& Korkeala, H. J. (1996). Evaluation of Lactobacillus sakei contamination in vacuum-packaged sliced cooked meat products by ribotyping. J Food Prot 59, 398-401.

De Ley, J., Cattoir, H. \& Reynaerts, A. (1970). Quantitative measurement of DNA hybridization from renaturation rates. Eur $J$ Biochem 12, 133-142.

Fujisawa, T., Benno, Y., Yaeshima, T. \& Mitsuoka, T. (1992). Taxonomic study of the Lactobacillus acidophilus group, with recognition of Lactobacillus gallinarum sp. nov. and Lactobacillus johnsonii sp. nov. and synonymy of Lactobacillus acidophilus group A3 (Johnson et al. 1980) with the type strain of Lactobacillus amylovorus (Nakamura 1981). Int J Syst Bacteriol 42, 487-491.

Gillis, M., De Ley, J. \& De Cleene, M. (1970). The determination of molecular weight of bacterial genome DNA from renaturation rates. Eur J Biochem 12, 143-153.

Huß, V. A. R., Festl, H. \& Schleifer, K. H. (1983). Studies on the spectrophotometric determination of DNA hybridization from renaturation rates. Syst Appl Microbiol 4, 184-192.

Hutton, J. R. (1977). Renaturation kinetics and thermal stability of DNA in aqueous solutions of formamide and urea. Nucleic Acids Res 4, 3537-3555.

Jakava-Viljanen, M. \& Palva, A. (2007). Characterization of Lactobacillus species carrying surface (S) layer protein isolated from porcine intestine and faeces and their adhesion to different host tissues. Vet Microbiol 124, 264-273.

Johnson, J. L., Phelps, C. F., Cummins, C. S., London, J. \& Gasser, F. (1980). Taxonomy of the Lactobacillus acidophilus group. Int J Syst Bacteriol 30, 53-68.

Konstantinov, S. R., Poznanski, E., Fuentes, S., Akkermans, A. D., Smidt, H. \& de Vos, W. M. (2006). Lactobacillus sobrius sp. nov., abundant in the intestine of weaning piglets. Int J Syst Evol Microbiol 56, 29-32.

Lapage, S. P., Sneath, P. H. A., Lessel, E. F., Skerman, V. B. D., Seelinger, H. P. R. \& Clark, W. A. (editors) (1992). International Code of Nomenclature of Bacteria (1990 Revision). Bacteriological Code. Washington, DC: American Society for Microbiology.

Lauer, E., Helming, C. \& Kandler, O. (1980). Heterogeneity of the species Lactobacillus acidophilus (Moro) Hansen and Mocquot as revealed by biochemical characteristics and DNA-DNA hybridization. Zentralbl Bakteriol Mikrobiol Hyg 1 Abt Orig C 1, 150-168.

Nakamura, L. K. (1981). Lactobacillus amylovorus, a new starchhydrolyzing species from cattle waste-corn fermentations. Int J Syst Bacteriol 31, 56-63.

Naser, S. M. (2006). A novel robust identification system of the lactic acid bacteria Enterococcus, Lactobacillus and Streptococcus based on pheS, rpoA and atpA multilocus sequence analysis. $\mathrm{PhD}$ thesis, Ghent University, Belgium.

Naser, S. M., Thompson, F. L., Hoste, B., Gevers, D., Dawyndt, P., Vancanneyt, M. \& Swings, J. (2005). Application of multilocus sequence analysis (MLSA) for rapid identification of Enterococcus species based on rpoA and pheS genes. Microbiology 151, 2141-2150.

Naser, S. M., Vancanneyt, M., Snauwaert, C., Vrancken, G., Hoste, B., De Vuyst, L. \& Swings, J. (2006). Reclassification of Lactobacillus amylophilus LMG 11400 and NRRL B-4435 as Lactobacillus amylotrophicus sp. nov. Int J Syst Evol Microbiol 56, 2523-2527.

Pitcher, D. G., Saunders, N. A. \& Owen, R. J. (1989). Rapid extraction of bacterial genomic DNA with guanidium thiocyanate. Lett Appl Microbiol 8, 151-156.

Ryu, C. S., Czajka, J. W., Sakamoto, M. \& Benno, Y. (2001). Characterization of the Lactobacillus casei group and the Lactobacillus acidophilus group by automated ribotyping. Microbiol Immunol 45, 271-275. 